\title{
PENGARUH JAMU CEKOK TERHADAP KENAIKAN BERAT BADAN DAN JUMLAH MAKANAN YANG DIKONSUMSI MENCIT
}

\author{
Sih Rini Handajani, KH Endah Widhiastuti \\ Kementerian Kesehatan Politeknik Kesehatan Surakarta Jurusan Kebidanan \\ Diterima : 2 Agustus 2018, Disetujui : 20 Agustus 2018
}

\begin{abstract}
Background: Javanese people, especially those living in the city of Solo, try to overcome the difficulty of eating children by providing special herbal medicine for children which is better known as jamu cekok. It's believed to have efficacy as a child's appetite stimulant, as a herb that can kill irritating worms in the body of a child. This study aimed to determine the effect of herbal medicine on weight gain and the amount of food consumed by mice. Method: This research design usedpre clinicaltria in mice. The sample consisted of 60 mice divided into 3 groups, namely 20 control groups, 20 treatment groups I (given $0.25 \mathrm{ml}$ slices) and Treatment Group II (given $0.5 \mathrm{ml}$ of stress). Result: The time for conducting research January 2016 s.d. June 2016 at the GadjahMada University Pharmacy Laboratory Yogjakarta. The results of the analysis of herbal medicine had an effect on the weight gain with the results in the intervention group 1, the consumption of herbal medicine decreased the weight of rats by $24.3 \%$. and in the intervention group 2 decreased the mouse rats by $0.1 \%$. Choking affects the amount of food left over. Conclusion: The results showed that the mice given $0.25 \mathrm{ml}$ less rest (amounting to 0.570 and this decrease occurred very significantly indicated by the $p$ value <0.000) compared to those given $0.50 \mathrm{ml}$ and control group
\end{abstract}

Keywords : Body Weight, Traditional Herbs

\section{PENDAHULUAN}

Kesulitan makan pada anak masih merupakan keluhan utama orang tua terhadap anaknya, terutama pada golongan balita. Pada usia toddler anak mengalami penurunan kebutuhan nutrisi yang dimanifestasikan dengan berkurangnya nafsu makan, fenomena ini dikenal sebagai anoreksia fisiologis (Wong, 2008). Masyarakat Jawa khususnya masyarakat yang tinggal di kota Solo berupaya mengatasi kesulitan makan anak dengan memberikan jamu khusus untuk anak-anak yang lebih dikenal dengan istilah jamu cekok. Istilah cekok mengacu pada cara atau metode pemberian jamu yaitu dengan dicekokkan atau dicangar (dimasukkan secara paksa) ke dalam mulut anak Bahan utama jamu cekok adalah empon-empon yang terdiri dari Curcuma xanthorriza Robx (temulawak), Zingiber americans $L$. (lempuyang emprit), Tinospora tuberculata Beume (brotowali), Curcuma aeruginaosa Robx (temu ireng) serta Carica papaya L. (papaya) (Limananti \&Triratnawati, 2003). Menurut Koperasi Jamu Indonesia (KOJAI) Sukoharjo (2009), ramuan jamu cekok yaitu beras, Daun Pepaya, Temu hitam, Temulawak, Kencur, Kunyit, dan Adas manis. Setelah itu diseduh dengan air panas, tambahkan gula merah, sedikit garam, dan asam jawa. 
Saring, lalu diminumkan pada anak agar tubuhnya hangat (Moertedjo, 2009).

Temulawak memiliki kandungan antioksidan seperti fenol, flavonoid dan kurkumin yang akan menangkap radikal bebas dalam tubuh. Flavonoid juga memiliki fungsi lain seperti menstabilisasi membran sel serta menginhibisi peroksidasi lipid, meningkatkan kandungan prostaglandin mukosa dan mukus di mukosa lambung dengan menstimulasi cyclooxygenase-1 (COX-1), mengurangi sekresi asam dan pepsinogen dalam lambung. Selain itu kurkumin yang dikandung oleh rimpang temulawak dapat menekan pembentukan tumor necrosis factor alpha (TNF- $\alpha$ ) sehingga mencegah aktifitas inflamasi yang akan menaikkan pembentukan radikal bebas dari proses fagositosis. Sehingga dapat disimpulkan bahwa temulawak memiliki potensi sebagai pencegah kerusakan mukosa lambung (Bintari, et.al, 2014)

Jamu cekok dipercaya memiliki khasiat sebagai perangsang nafsumakan anak, sebagai ramuan yang dapat membunuh cacing pengganggu dalam tubuh anak. Secara umum proses kerja obat penambah nafsu makan anak adalah meningkatkan metabolisme, menekan dan menghambat asam lambung, serta merangsang sekresi makanan sehingga meningkatkan nafsu makan (Handayani, 2002). Memberikan jamu cekok setiap satu minggu sekali secara rutin diharapkan dapat meningkatnya nafsu makan anak sehingga dapat mendorong peningkatan asupan nutrisi mengingat kebutuhan balita akan kalori, protein, cairan dan mineral masih relatif tinggi (Wong, 2008). Data studi pendahuluan dan wawancara orangtua yang dilakukan pada 5 balita yang diberi jamu cekok menunjukkan peningkatan berat badan antara 200 sampai 300 gram sebulan. Berat badan 3 orang balita meningkat 300 gram sedangkan 2 balita yang lain meningkat 200 gram sebulan. Orang tua balita mengatakan bahwa mereka masih mempercayai budaya tersebut dan melakukan secara turun temurun dari nenek moyangnya. Berdasarkan data tersebut berat badan anak yang diberi jamu cekok setiap satu minggu sekali secara teratur, dalam sebulan pertumbuhan berat badannya mengalami peningkatan rata-rata 260 gram perbulan. Penelitian ini bertujuan untuk mengetahui pengaruh jamu cekok terhadap kenaikan berat badan dan jumlah makanan yang dikonsumsi mencit.

\section{METODE PENELITIAN}

Dalam menganalisis pengaruh cekok terhadap kenaikan berat badan dan jumlah makanan yang di konsumsi mencit maka jenis penelitian yang digunakan adalah uji pra klinis (pra clinical trial) pada mencit. Pada uji klinis peneliti memberikan perlakuan atau intervensi kepada anak mencit yang yang mempunyai berat sama kemudian diberikan cekok selama 14 hari berturut turut dan diamati setiap harinya mulai hari ke 0 sampai hari ke 14 pada jam yang sama dan akan di lihat perubahan tentang berat badan dan jumlah makanan yang di konsumsi mencit. Populasi dalam penelitian ini adalah terdiri dari 60 ekor anak mencit yang usia dan berat badan sama. Sebagai sampel dalam penelitian ini adalah 60 anak mencit betina yang dibagi 3 kelompok dengan teknik samplingnya adalah purposive sampling dengan kriteria: Anak mencit sehat, Jenis kelamin mencit betina, Berat badan awal mencit sama baik control maupun perlakuan, Usia mencit sama diambil usia usia 3 minggu 
dengan alasan usia ini sudah di sapih dari induknya dengan analog seusia balita bila pada manusia dan Apabila anak mencit selama penelitian terdapat mati maka sample di anggap drop out.

Variabel bebas dalam penelitian ini adalah pemberian jamu cekok, variabel terikatnya yaitu kenaikan berat badan dan jumlah makanan yang di konsumsi. Selain itu terdapat variabel antara yaitu nutrisi. Instrumen yang digunakan untuk mengumpulkan data penelitian dari: Timbangan Triple Beam O House dalam satuan ukuran gram, digunakan untuk menimbang anak mencit, Pipe tukuran 0.25 dan ukuran $0,5 \mathrm{ml}$, digunakan untuk memberikan minum jamu cekok dengan alas an sesuai dengan kapasitas lambung mencit, Lembar pencatatan hasil pengamatan berat badan dan jumlah makanan yang di konsumsi anak mencit setiap harinya dan Almaries yang digunakan untuk menyimpan sediaan jamu cekok. Cekok berasal dari salah satu penjual jamu yang ada di Jagalan kota Surakarta yang terdiri dari daun papaya, Temulawak, Temu hitam, Kunyit, dan Adas yang disediakan dalam bentuk jamu yang dicekokkan pada balita. Waktu pelaksanaan penelitian adalah pada Bulan Januari 2016 s.d. Juni 2016 di laboratorium Farmasi Universitas Gadjah Mada Yogjakarta. Deskripsi Perlakuan untuk mengumpulkan data tentang berat badan dan jumlah konsumsi makanan mencit baik kelompok kontrol maupun kelompok perlakuan adalah dengan caraAnak mencit diberikan dengan pipet jamu cekok dan disiapkan makanan dengan jumlah tertentu dan Di timbang setiap hari dan diamati jumlah makanan yang di konsumsi setiap hari selama 14 hari:Kelompok Perlakuan I (diberikan cekok 0,25 ml), Kelompok Perlakuan II (diberi cekok 0,5 ml), dan Kelompok kontrol (tanpa diberi jamu cekok). Analisis univariat dalam bentuk tendency central sementara untuk analisis bivariat menggunakan normal menggunakan repeated ANOVA, tapi bila data tidak terdistribusi normal, akan menggunakan uji Friedman test.

\section{HASIL PENELITIAN \\ 1. Pengaruh Cekok dengan Berat Badan Pre dan Post}

Tabel 1. Pengaruh Cekok dengan Berat Badan Pre dan Post

\begin{tabular}{lcll}
\hline Kelompok & Pre test & Post test & $\begin{array}{c}\text { Nilai } \boldsymbol{\rho} \\
\text { Box's Test Of Equality }\end{array}$ \\
\hline Kontrol (n=20) & & & \\
$\quad$ Mean & $\mathbf{2 9 , 2 5}$ & $\mathbf{2 4 , 3 6}$ & $<0,001$ \\
$\quad$ SD & 2,73 & $\mathbf{4 , 2 6}$ & \\
Perlakuan 1(n=20) & & & \\
$\quad$ Mean & 25,97 & $\mathbf{2 3 , 8 0 5}$ & \\
$\quad$ SD & 0,96 & $\mathbf{2 3 , 2 3}$ & \\
& & & \\
Perlakuan 2(n=20) & & & \\
$\quad$ Mean & 23,36 & $\mathbf{2 3 , 8 0}$ & \\
SD & 0,89 & $\mathbf{2 , 9 3}$ &
\end{tabular}

\section{Pada Tabel 1 di informasikan Nilai}

Box's M menunjukkan homogenitas skor kemandirian pada kelompok eksperimen dan kontrol. Nilai sig. yang dibawah 0.05 menunjukkan data tidak homogen atau variasi skor kemandirian pada masingmasing kelompok sangat bervariasi. Dalam eksperimen ketidak homogenan ini tidak menjadi masalah, karena kita sulit untuk mendapatkan variasi skor yang sama pada dua kelompok yang dikenai perlakuan yang berbeda dalam penelitian yang menggunakan desain kuasi eksperimen dan bukan eksperimen murni. Dalam kuasi eksperimen, faktor error (subjek, sampel, perlakuan, dsb) sangat berpengaruh sehingga perubahan skor subjek dari pre-test menuju post-test sangat bervariasi. 
Tabel 2. Uji interaksi antara waktu (prepost) dan kelompok (kontrol, intervensi 1, dan intervensi 2)

$\begin{array}{lll}\begin{array}{l}\text { Variabel } \\ \text { interaksi }\end{array} & \text { Uji } & \text { P value* }\end{array}$

kontrol, intervensi 1, $<0,001 \quad \mathrm{~F}=22.194$

danintervensi 2

Keterangan Uji: *)Mauchly's Test of Sphericity ${ }^{b}$

Pada tabel 2 Nilai Mauchly's Test

of Sphericitybdidapatkan hasil yang signifikan (sig. $<0,05)$. Dengan hasil ini maka dilanjutkan pada tabel Tests of Within-Subjects Effects, hasilnya adalah $\mathrm{F}=22.194(\mathrm{P}<0.000)$ artinya bahwa pada penelitian ini terdapat interaksi antara waktu (pre-post) dan kelompok (kontrol, intervensi 1, dan intervensi 2). Interaksi menunjukkan bahwa perubahan BB pre menuju post pada ketiga kelompok adalah berbeda secara signifikan.

Tabel 3. Pengaruh berat camu cekok pada berat badan mencit

\begin{tabular}{|c|c|c|c|c|c|c|}
\hline \multirow[t]{2}{*}{ Kelompok } & \multirow[t]{2}{*}{ Waktu } & \multirow[t]{2}{*}{$\begin{array}{l}\text { Mean } \\
\text { difference }\end{array}$} & \multirow[t]{2}{*}{$S E$} & \multirow[t]{2}{*}{$\begin{array}{l}P \\
\text { Value }\end{array}$} & \multicolumn{2}{|c|}{$\begin{array}{c}95 \% \\
\text { Confidence } \\
\text { Interval }\end{array}$} \\
\hline & & & & & Lower & Upper \\
\hline Kontrol & $1-2$ & 4,880 & 0,506 & $<0,001$ & 3,866 & 5,894 \\
\hline Intervensi1 & $1-2$ & 2,165 & 0,506 & $<0,001$ & 1,151 & 3,379 \\
\hline Intervensi2 & $1-2$ & 0,125 & 0,506 & 0,806 & $\begin{array}{l}- \\
0,889\end{array}$ & 1,139 \\
\hline
\end{tabular}

Tabel 3 berdasarkan ujipairwise comparisons diatas menunjukkan bahwa pada kelompok kontrol didapatkan nilai $(\mathrm{MD}=4.880, \quad \mathrm{P}<0.000)$ hal ini berarti bahwa pada kelompok kontrol terjadi penurunan rerata pre dibanding rerata post (pre lebih tinggi dari pada post) sebesar 4.880 dan penurunan ini terjadi secara signifikan ditunjukkan dengan nilai $\mathrm{p}<0.000$. sedangkan pada kelompok intervensi 1 didapatkan nilai $(\mathrm{MD}=2.165$, $\mathrm{P}<0.000$ ) hal ini berarti bahwa pada kelompok intervensi 1 terjadi penurunan rerata pre dibanding rerata post (pre lebih tinggi dari pada post) sebesar 2.165 dan penurunan ini terjadi secara signifikan ditunjukkan dengan nilai $\mathrm{p}<0.000$ sedangkan pada kelompok intervensi 2 didapatkan nilai ( $\mathrm{MD}=0.125, \mathrm{P}>0.05)$ hal ini berarti bahwa pada kelompok intervensi 2 terjadi penurunan rerata pre dibanding rerata post (pre lebih tinggi dari pada post) sebesar 0.125 namun penurunan ini tidak signifikan ditunjukkan dengan nilai $\mathrm{p}>0.05$.

Tabel 4. Analisis Multivariat Pengaruh Jamu Cekok Terhadap Kenaikan Berat Badan Dan Jumlah Makanan Yang Dikonsumsi Mencit

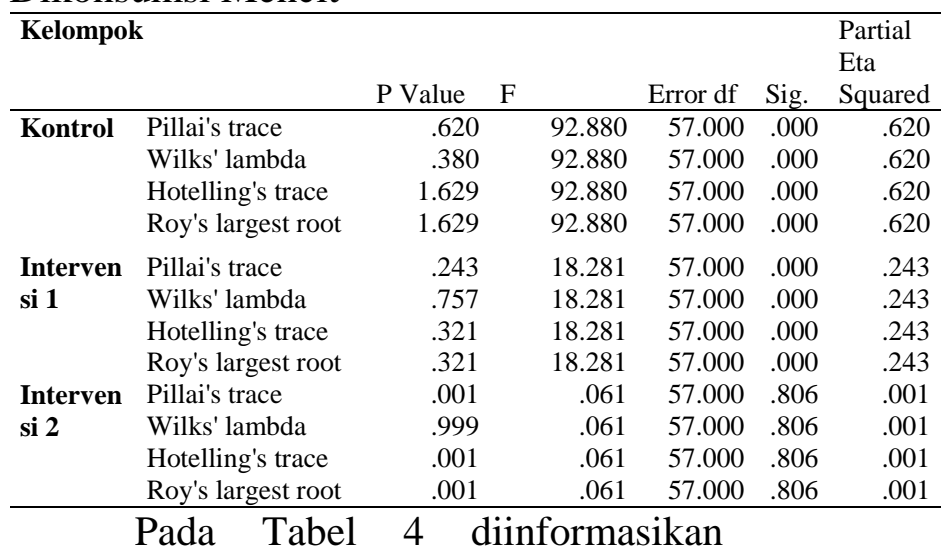

karena didapatkan hasil pada pairwise comparison terjadi penuruan pada prepost sehingga pada multivariate test disini dapat dilihat prosentasi efektivitasnya. Pada kelompok kontrol ternyata menurunkan berat badan tikus sebesar $62.0 \%$, sedangkan pada kelompok intervensi 1 pemberian konsumsi jamu menurunkan BB tikus sebesar $24.3 \%$. dan pada kelompok intervensi 2 menurunkan BB tikus sebesar $0.1 \%$. 
2. Pengaruh Cekok Terhadap Sisa Makanan

Tabel 5. Pengaruh Cekok Terhadap Sisa

Makanan

\begin{tabular}{lllllll}
\hline & Kelompok & & & & $\begin{array}{l}\text { Box's } \\
\text { Test of } \\
\text { Equality }\end{array}$ & F \\
& & Mean & SD & N & Eq476 \\
Sisa & Kontrol & .9300 & .74346 & 20 & 15,649 & 2,476 \\
Pre test & Intervensi 1 & .9700 & .54396 & 20 & & \\
& Intervensi 2 & .7650 & .54606 & 20 & & \\
& Total & .8883 & .61426 & 60 & & \\
Sisa & Kontrol & .6450 & .70298 & 20 & & \\
Post & Intervensi 1 & .4000 & .43042 & 20 & & \\
Test & Intervensi 2 & .4750 & .41279 & 20 & & \\
& Total & .5067 & .53326 & 60 & & \\
\hline \multicolumn{2}{c}{ Pada } & Tabel 5 & dijelaskan & Nilai
\end{tabular}

Box's $M$ menunjukkan homogenitas skor kemandirian pada kelompok eksperimen dan kontrol. Nilai sig. (0.021) yang dibawah 0.05 menunjukkan data tidak homogen atau variasi skor kemandirian pada masing-masing kelompok sangat bervariasi. Dalam eksperimen ketidakhomogenan ini tidak menjadi masalah, karena kita sulit untuk mendapatkan variasi skor yang sama pada dua kelompok yang dikenai perlakuan yang berbeda dalam penelitian yang menggunakan desain kuasi eksperimen dan bukan eksperimen murni. Dalam kuasi eksperimen, faktor error (subjek, sampel, perlakuan, dsb) sangat berpengaruh sehingga perubahan skor subjek dari pre-test menuju post-test sangat bervariasi.

Tabel 6. Uji interaksi antara time (prepost) dan kelompok (kontrol, intervensi 1, dan intervensi 2)

\begin{tabular}{ccc}
\hline $\begin{array}{l}\text { Mauchly's Test of } \\
\text { Sphericity }\end{array}$ & $\begin{array}{l}\text { Tests of Within- } \\
\text { Subjects Effects }\end{array}$ \\
\hline P value $<0,001$ & F & 1,339 \\
\hline Pada tabel 6 dijelaskan Mauchly's
\end{tabular}

Test of Sphericitydidapatkan hasil yang signifikan (sig.<0,05). Dengan hasil ini maka dilanjutkan pada tabel Tests of Within-Subjects Effects, hasilnya adalah $\mathrm{F}=1.339 \quad(\mathrm{P}=0.270>0.05)$ artinya bahwa pada penelitian ini tidak terdapat interaksi antara time (pre-post) dan kelompok (kontrol, intervensi 1, dan intervensi 2). Interaksi menunjukkan bahwa tidak ada perubahan yang signifikan antara sisa makanan pre dan sisa makanan post.

\section{PEMBAHASAN}

Istilah cekok mengandung maksud pemaksaan, sama artinya dengan dicangar. Cekok dalam Bahasa Indonesia berarti obat tradisional dengan ramuan daun-daunan yang dilumat lalu diminumkan secara paksa kepada si sakit misalnya seperti pada anak kecil yang enggan menelan obat (Limananti, 2003).

Mencekok berarti meminumkan secara paksa (Badudu, Zain, 1994). Sedangkan dicangar berasal dari kata dasar cangar atau nyangar yang berarti membuka mulut dengan paksa untuk diminumi jamu (Widada, 2001).

Ramuan jamu cekok terdiri dari Daun Pepaya, Temulawak, Temu hitam, Kunyit, Adas, Pulosari, Kayu manis dan Pala. Bahan-bahan tersebut dicuci bersih kemudian dikupas dan ditumbuk. Setelah itu dikukus dengan cara dibungkus menggunakan daun pisang. Sedangkan pada penelitian ini cekok yang digunakan adalah ramuan tradisional yang berupa campuran dari daun pepaya, temulawak, temuireng, kunyit, adas, pulosari, kayu manis, dan pala yang dihaluskan kemudian sari-sarinya diberikan dengan cara dip eras diberikan pada mencit.

Jamu cekok dipilih dengan tujuan utama untuk meningkatkan nafsu makan anak. Selain itu ada manfaat lain yaitu mengobati penyakit ringan yang diderita anak-anak seperti cacingan, mencret, perut kembung, batuk, pilek, dan sebagainya. Kondisi ini serupa dengan yang ada di Thailand dimana jamu juga banyak 
digunakan untuk penyembuhan penyakit yang berkaitan dengan perut. Hal ini tidak lepas dari faktor kepercayaan dan keyakinan akan khasiat jamu cekok anak yang telah tertanam sejak anak-anak, karena umumnya tradisi ini diwariskan dalam keluarga melalui orang tua (Limananti, Triratnawati, 2003 ; Handayani, 2002; Wong, 2008).

Dari hasil penelitian didapatkan pada kelompok kontrol ternyata menurunkan berat badan tikus sebesar $62.0 \%$, sedangkan pada kelompok intervensi 1 pemberian konsumsi jamu menurunkan BB tikus sebesar $24.3 \%$. dan pada kelompok intervensi 2 menurunkan BB tikus sebesar $0.1 \%$ sehingga $\mathrm{Ha}$ diterima dimana jamu cekok berpengaruh terhadap kenaikan berat badan dan jumlah makanan yang di konsumsi mencit hal ini sesuai dengan hasil penelitian yang dilakukan oleh Limananti, Triratnawati (2003) dan Marni, Retno (2015) dimana cekok bisa meningkat berat badan pada anak. Bahan-bahan utama ramuan jamu cekok atau bahan-bahan generik jamu cekok yaitu sebagai berikut : Daun Pepaya, Temulawak, Temu hitam, Kunyit, dan Adas yang masing-masing memiliki khasiat. Pepaya (Carica papaya) merupakan tumbuhan yang berbatang tegak dan basah. Khasiat untuk kesehatan, tanaman pepaya terdapat hampir pada seluruh bagian tumbuhan. Daun Pepaya berkhasiat untuk mengobati batu ginjal, hipertensi, malaria, keputihan, malnutrisi pada anak-anak, dan mengobati nyeri haid. Buah pepaya yang masih mengkal memiliki efek menggugurkan kandungan. Selain itu daun pepaya mengandung vitamin A $1850 \mathrm{SL}$, vitamin B $0.15 \mathrm{mg}$, vitamin C $140 \mathrm{mg}$, kalori 79 kalori, protein 8.0 gram, lemak 2 gram, hidrat arang $11.9 \mathrm{mg}$, kalori 79 kalori, protein
8.0 gram, besi $0,8 \mathrm{mg}$, air 75,4 gram, carposide, papa-yotin, karpai, kausyuk, karposit dan vitamin yang dibutuhkan untuk pertumbuhan bayi dan kesehatan ibu, sehingga dapat menjadi sumber gizi yang sangat potensial. Kandungan protein tinggi, lemak tinggi, vitamin, kalsium dan zat besi dalam daun papaya berfungsi untuk pembentukan hemoglobin.Apabila hemoglobin dalam darah meningkat, diharapkan $\mathrm{O} 2$ dalam darah meningkat, metabolisme juga meningkat sehingga sel otak berfungsi dengan baik dan kecerdasan meningkat. Temulawak (Curcuma xanthorrizha) berfungsi untuk mengobati sakit limpa, sakit ginjal, sakit pinggang, asma, sakit kepala, masuk angin, sakit perut, meningkatkan produksi ASI, meningkatkan nafsu makan, sembelit, sakit cangkrang, cacar air, sariawan, dan jerawat. Rimpang temulawak mengandung kurkumin, xhantorizol, kurkuminoid, minyak atsiri dengan komponen $\alpha$-kurkumen, germakram, ar-tumeron, $\beta$-atlantanton, $d$ kamfor (KEMENKES RI, 2010). Selain itu temulawak juga mengandung zat gizi antara lain karbohidrat, protein, lemak serta serat kasar dan mineral seperti Kalium (K), Magnesium (Mg), Mangan (Mn), dan Kadmium (Cd) (Aspan, 2006). Kandungan lain dari cekok adalah temu hitam (Curcuma aeruginosa) yang berkhasiat untuk kesehatan yaitu kandungan zat dalam rimpangnya berkhasiat untuk mengatasi tidak nafsu makan, melancarkan keluarnya darah kotor setelah melahirkan, penyakit kulit seperti kudis, ruam, dan borok, perut mulas, sariawan, batuk, sesak napas, dan cacingan. Rimpang Temu hitam mengandung minyak atsiri, tanin, kurkumol, kurkumenol, isokurkumenol, kurzerenon, kurdion, kurkumalakton, 
germakron, linderazulene, kurkumin, demethyoxykurkumin, bisdemethyoxykurku min. Kunyit (Curcuma longa) bahan selanjutnya untuk pembuatan cekok yang mempunyai khasiat untuk kesehatan antara lain untuk mengobati sakit diabetes melitus, tifus, usus buntu, disentri, keputihan, haid tidak lancar, nyeri haid, memperlancar ASI, dan amandel. Kunyit mengandung senyawa kurkuminoid yang terdiri dari kurkumin, desmetoksikumin, dan bisdesmetoksikurkumin dan zat-zat manfaat lainnya. Bahan cekok yang terakhir adalah adas (Foeniculum vulgare) yang berkhasiat untuk kesehatan dapat digunakan untuk mengatasi sakit perut (mulas), perut kembung, mual, muntah, ASI sedikit, diare, sakit kuning, kurang nafsu makan, batuk, sesak napas (asma), nyeri haid, haid tidak teratur, rematik goat, susah tidur (insomnia), buah pelir turun, kolik, usus turun ke lipat paha, batu empedu, pembengkakan saluran sperma, penimbunan cairan dalam kantung buah zakar, keracunan tumbuhan obat atau jamur, dan meningkatkan penglihatan. Kandungan kimia dalam Adas yaitu mengandung minyak atsiri, anetol, fenkon, pinen, limonen, dipenten, felandren, metilchavikol, anisaldehid, asam anisat, dan minyak lemak. Akar tanaman Adas mengandung bergapten, akar dan biji mengandung stigmasterin(serposterin).

Bahan-bahan tersebut mempunyai khasiat untuk menambah nafsu makan sehingga berat badan anak menjadi meningkat. Dari hasil penelitian didapatkan, mencit yang mendapat cekok $0,50 \mathrm{ml}$ mengalami penikngkatan berat badan lebih dari mencit yang diberikan cekok sebanyak 0m25 ml maupun yang tidak diberikan cekok. Cekok merupakan bagian budayaJawa khususnya masyarakat yang tinggal di kota Solo dalam upaya mengatasi kesulitan makan anak dengan memberikan jamu khusus untuk anakanak (Limananti, Triratnawati, 2003). Bahan dari cekok juga belum ada yang menunjukkan efek samping yang berbahaya bagi manusia, karena semua kandungan berkhasiat untuk kesehatan dan juga peningkatan berat badan serta nafsu makan (Bianti, et all,)

Untuk jumlah makanan yang dikonsumsi, hasil penelitian menunjukkan bahwa mencit yang diberikan cekok 0,25 $\mathrm{ml}$ lebih sedikit sisanya (sebesar 0.570 dan penurunan ini terjadi secara sangat signifikan ditunjukkan dengan nilai $\mathrm{p}<0.000)$ dibandingkan dengan yang diberi cekok $0,50 \mathrm{ml}$ dan kelompok kontrol. Hal ini bisa dibebabkan dari khasiat temulawak, temu hitam dan adas yaitu salah satunya dapat meningkatkan nafsu makan (Aspan, 2006)

\section{KESIMPULAN DAN SARAN}

Jamu cekok berpengaruh terhadap kenaikan berat badan dengan hasil pada kelompok intervensi 1 pemberian konsumsi jamu menurunkan BB tikus sebesar $24.3 \%$. dan pada kelompok intervensi 2 menurunkan BB tikus sebesar $0.1 \%$. Cekok berpengaruh terhadap jumlah sisa makanan. Hasil penelitian menunjukkan bahwa mencit yang diberikan cekok $0,25 \mathrm{ml}$ lebih sedikit sisanya (sebesar 0.570 dan penurunan ini terjadi secara sangat signifikan ditunjukkan dengan nilai $\mathrm{p}<0.000$ ) dibandingkan dengan yang diberi cekok 0,50 ml dan kelompok kontrol. Disarankan Melanjutkan penelitian dengan topik yang sama, metode yang berbeda dan sampel ke manusia yang menggunakan jamu cekok yang sebelumnya harus distandarisasi dan uji organoleptik, rasa dan uji toksisitas. 
Melakukan scintifikasi jamu cekok sehingga bisa menjadi alternatif dalam meningkatkan berat badan pada bayi dan balita.

\section{DAFTAR RUJUKAN}

Badudu JS, Zain SM. 1994. Kamus Umum Bahasa Indonesia. Jakarta: Pustaka Sinar Harapan.

Bintari, Windarti, Fiana 2014. Temulawak (Curcuma xanthorrhiza Roxb) as Gastroprotector of Mucosal Cell Damage. Majority, vol 3 no 5 hal. 77-84.

Limananti I, Triratnawati A. 2003. Ramuan Jamu Cekok Sebagai Penyembuhan Kurang Nafsu Makan pada Anak. Makara, Kesehatan, Vol. 7, No. 1, Juni 2003.

Moertedjo. 2009. Aneka Resep Obat Tradisional Asli Indonesia. Koperasi Jamu Indonesia (KOJAI) Sukoharjo.

http://jamusukoharjo.wordpress.co

m/category/resep-jamu-jawa/ (diakses tanggal 6 Oktober 2013).

Widada, dkk. 2001. Kamus Bahasa Jawa. Jogjakarta: Kanisius.

Wong, D. L. 2008. Buku Ajar Keperawatan Pediatrik Wong. Jakarta : EGC. 